\title{
МЕТОДИКА ФОРМУВАННЯ ПРОЕКТНО-АНАЛІТИЧНОЇ КОМПЕТЕНТНОСТІ МАЙБУТНІХ ОФІЦЕРІВ-ПРИКОРДОННИКІВ У ПРОЦЕСІ ФАХОВОЇ ПІДГОТОВКИ
}

humanities. Procedings of the VI International Internet Conference of Young Scientists and Students, September 27 - 29th, 2016.(pp.54-58). Gluxiv: RVV Gluxivskogo NPU im. O. Dovzhenka. [in Ukrainian].

6. Dolinnyj, Yr.A. (2016). Suchasni teoretychni osnovy pidgotovky majbutnix faxivciv z fizychnogo vyxovannya i sportu do reabilitacijnoyi roboty [Modern theoretical bases of preparation of future specialists are on P.E and sport to rehabilitation work]. "Pedagogyka $i$ sovremtnnyi aspekty fizicheskogo vospitanya": $z b$. nauk. pracz II Mizhnar. nauk.-prakt. konf., (21-22 kvitnya 2016 roku). -"Pedagogy and modern aspects of physical education": A collection of scientific works II International Science-Practice Conference. (April 2122th, 2016). (pp. 235-241). Kramatorsk: DDMA. [in Ukrainian].

7. Orzhekhovska, V. M. (2011). Zdoroviazberezhuvalne navchannia $i$ vykhovannia [To health activity of studies and education]. Naukovi zapysky NDU im. M. Hoholia: Psykholoho-pedahohichni nauky, no. 4, pp. 29-31. [in Ukrainian].

8. Pieshkova, O.V. (2007). Vstup do spetsialnosti (Fizychna reabilitatsiia) [A prelude is of speciality (Physical rehabilitation)]. Kharkiv, 147p. [in Ukrainian].

9. Popov, S. N. (2006). Fizicheskaya reabilitatsiya [Physical rehabilitation]. Rostov n/D.: Feniks, 608p. [in Russian].

10. Prykhoda, I. V. (2007). Orhanizatsiinometodolohichni pidkhody do profesiinoi pidhotovky fakhivtsiv $z$ fizychnoi reabilitatsii $v$ Ukraini [Organizationally-methodological going near professional preparation of specialists on a physical rehabilitation in Ukraine]. Problemy suchasnoi pedahohichnoi osvity, vol. 15, part. 1, pp. $60-66$. [in Ukrainian].

Стаття надійшла до редакції 28.02.2018

УДК 355(477):004:378:377:14:001

DOI:

Юрій Мельничук, ад ’юнкт кафедри педагогіки та соціально-економічних дисциилін, факультет іноземних мов і гуманітарних дисциплін

Національна академія Державної прикордонної служби України імені Богдана Хмельницького

\section{МЕТОДИКА ФОРМУВАННЯ ПРОЕКТНО-АНАЛІТИЧНОЇ КОМПЕТЕНТНОСТІ МАЙБУТНІХ ОФІЦЕРІВ-ПРИКОРДОННИКІВ У ПРОЦЕСІ ФАХОВОЇ ПІДГОТОВКИ}

Стаття присвячена проблемі формування проектно-аналітичної компетентності майбутніх офіиеерів-прикордонників. Визначено зміст понять “проектно-аналітична компетентність”. Розкрито структуру “проектно-аналітичної компетентності майбутніх офіцерів-прикордонників”.

На основі аналізу структури проектно-аналітичноӥ компетентності майбутніх офіцерівприкордонників автор визначив методику ї̈ формування, яка є поетапною. Розкрито зміст кожного етапу щуодо формування проектно-аналітичної компетентності майбутніх офіцерів-прикордонників.

Ключові слова: проектно-аналітична компетентність, проектна культура, аналітична діяльність, майбутні офіцери-прикордонники, професійна підготовка, методика формування компетентності.

Лim. 13.

Yuriy Melnychuk, Adjunct of the Pedagogy and Socio-Economic Disciplines Department, Faculty of Foreign Languages and Humanities National Bohdan Khmelnytskiy Academy of the State Border Guard Service of Ukraine

\section{METHOD OF FORMATION OF PROJECT-ANALYTICAL COMPETENCE OF FUTURE OFFICERS-BORDERS IN THE PROCESS OF PROFESSIONAL PREPARATION}

The transition of Ukrainian higher education to the European model has caused the need to change the various aspects of the educational process. One of the main contradictions was the non-compliance with the requirements of the modern market system and the results of the professional training of graduates of higher educational institutions.

Modern society considers a specialist not only as a person who possesses knowledge, skills and skills of the professional sphere, but also is capable to effectively operate in the complex, sometimes non-standard situations, that is, competent. In these conditions, a growing competence becomes more and more competent, in particular, its implementation into the training of future border guards officers.

The article is devoted to the problem of the design and analytical competence of future officers-border guards. The content of the concepts "design and analytical competence" is determined. The structure of "design and analytical competence of future officers-border guards" is revealed.

On the basis of analysis of the structure of the design and analytical competence of future officersborder guards, the author determined the method of its formation, which is a phased process. The content of each stage is discussed in relation to the design and analytical competence of future officers-border guards.

Consequently, a thorough analysis of scientific literature made it possible to reveal the contents of the $P A C$ of the ILO, and, on the basis of it, to formulate methodological recommendations for its formation. 


\section{МЕТОДИКА ФОРМУВАННЯ ПРОЕКТНО-АНАЛІТИЧНОӤ КОМПЕТЕНТНОСТІ МАЙБУТНІХ ОФІЦЕРІВ-ПРИКОРДОННИКІВ У ПРОЦЕСІ ФАХОВОЇ ПІДГОТОВКИ}

Thus, the set of analyzed theoretical and methodological approaches will allow to comprehensively explore the methodology of forming the design and analytical competence of future officers-border guards.

In the context of solving the problem of forming the design and analytical competence of future officersborder guards, the issues of introducing the technology of formation of the indicated competence into the educational process of higher military educational institutions are relevant.

Keywords: design and analytical competence, design culture, analytical activity, the future officers-border guards, professional training, the methods of forming competency.

П остановка проблеми у загальному вигляді. Перехід української вищої освіти на європейську модель викликав необхідність зміни різних сторін освітнього процесу. Однією 3 основних суперечностей стала невідповідність вимогам сучасної ринкової системи і результатів професійної підготовки випускників вищих навчальних закладів.

Сучасне суспільство розглядає фахівця не тільки як людину, що володіє знаннями, уміннями і навичками в професійній сфері, але і як здатного ефективно діяти в складних, часом нестандартних ситуаціях, тобто компетентного. У цих умовах все більшої обгрунтованості набуває компетентністний підхід, зокрема його впровадження у професійну підготовку майбутніх офіцерів-прикордонників.

Метою статті є аналіз методики формування проектно-аналітичної компетентності майбутніх офіцерів-прикордонників.

Аналіз останніх досліджень і публікацій, в яких започатковано вирішення даної проблеми та на які опирасться автор. Розглянемо теоретико-методологічні засади формування проектно-аналітичної компетентності майбутніх фахівців у вітчизняній та зарубіжній науковій літературі: Е. Зеер [5] (професійна компетентність), Л. Тархан [11] (дидактична компетентність), Л. Усеінова [12] (професійно-практична компетентність), О. Шаріпова [13] (професійнопедагогічна компетентність) та інших. Слід згадати наукові праці С. Артюха [7], Н. Брюханової [2], О. Коваленко [8], О. Овчарук [10], в яких започатковано основи щодо удосконалення професійної підготовки майбутніх фахівців. Питання аналітичної компетентність майбутніх спеціалістів висвітлено в наукових працях I. Абрамової [1] та Н. Зинчук [6], а також в наукових публікаціях Н. Волкової [3] (інформаційно-аналітична компетентність майбутніх фахівців), О. Максимової [9] та інших.

Виклад основного матеріалу дослідження. Відповідно до існуючого стандарту, майбутній офіцер-прикордонник повинен бути підготовлений до професійної, соціально-педагогічної, культурноосвітньої, організаційно-управлінської, фізкультурноспортивної і спеціальної діяльності. Таким чином, майбутній офіцер-прикордонник повинен володіти професійною компетентністю в цих видах діяльності.
Інтегруючими компонентами в структурі професійної компетентності майбугнього офіцераприкордонника, на наш погляд, виступає проектна та аналітична компетентність.

Виходячи 3 розуміння сутності професійної компетентності та змісту професійної освіти майбутніх офіцерів-прикордонників, якісною характеристикою оволодіння курсантами професійною діяльністю $\epsilon$, на нашу думку, їх аналітична та проектна компетентність. У сучасному переліку складових професійної компетентності, аналітична та проектна відсутні. Проектна діяльність $\epsilon$ культурною та творчою формою діяльності, в процесі якої відбувається формування здатності до реалізації усвідомленого та відповідального вибору. Ця діяльність сприяе формуванню адаптивних навичок, вмінню орієнтуватись в різноманітних ситуаціях та різних колективах. Проектна діяльність сприяє формуванню дослідницьких навичок, а також умінь співпрацювати та висловлювати свою точку зору. Проектування у процесі освітньої діяльності, формує у курсантів-прикордонників вміння висловлювати проблему, здійснювати постановку завдань у відповідності із проблемою, здійснювати планування змістовної діяльності, самоаналізута рефлексії, представляти результати роботи, здійснювати пошук та відбір актуальної інформації, обирати відповідні технології для виготовлення продукту проектування.

Проте фундаментальність проектноаналітичної компетентності є безсумнівною, оскільки ця компетентність $\epsilon$ інтегральною характеристикою особистості майбутнього офіцера-прикордонника, що спрямована на уміння аналізувати інформацію $з$ метою їі використання в освітній та професійній діяльності; на розв'язання навчальних та професійних задач методом аналізу в умовах неповної поінформованості; на уміння аналізувати власну освітню та професійну діяльність 3 метою підвищення її ефективності; на розуміння та усвідомлення відповідних питань освітньої та професійної діяльності через аналітичну діяльність; на здатність розробляти та реалізувати проектну діяльність.

Результати аналізу психолого-педагогічних джерел, проектну компетентність сприймають як інтегративну характеристику суб'єкта діяльності, 


\section{МЕТОДИКА ФОРМУВАННЯ ПРОЕКТНО-АНАЛІТИЧНОЇ КОМПЕТЕНТНОСТІ МАЙБУТНІХ ОФІЦЕРІВ-ПРИКОРДОННИКІВ У ПРОЦЕСІ ФАХОВОӤ ПІДГОТОВКИ}

що передбачає здатність і готовність людини до ефективного самостійного здійснення теоретикопрактичної розробки проектів та реалізації їх в усіх сферах соціокультурної практики. В основі проектної компетентності - проектна діяльність, тобто процес проектування. Проектна діяльність визначається: усвідомленням змісту та значення процесу проектування, володінням спеціальними знаннями, уміннями та навичками, здатністю обирати, оптимізувати та використовувати отримані знання та набуті уміння і навички.

Проектна діяльність - це діяльність, спрямована на досягнення мети шляхом детальної розробки проблеми або технології, яка повинна закінчитись певним практичним результатом, що необхідно оформити.

Змістом проектної діяльності є перенесення відповідних знань, умінь та навичок у якіснокількісний формат. Проектна діяльність та проектне мислення становлять основу проектної культури. Ключовою характеристикою проектної діяльності є здатність планувати, перетворювати на основі заздалегідь продуманих проектів. Ключовим поняттям у проектній діяльності $€$ "проект".

На основі узагальнення теоретичного матеріалу щодо проектної діяльності, вважаємо, що під проектною діяльністю майбутнього офіцераприкордонника слід розуміти самостійну діяльність щодо реалізації професійних та індивідуальних програм від “задуму до результату".

Розглянемо зміст аналітичної діяльності майбутніх фахівців. За результатами досліджень наукової літератури, під аналітичною діяльністю розуміють комплекс особистісних та професійних якостей, аналітичні здібності, позитивну мотивацію та усвідомлення необхідності проведення професійної діяльності, відповідної системи знань та умінь в повсякденній та професійній сфері.

Щодо аналізу досліджень з питань формування аналітичної компетентності, то існують різні підходи до розкриття змісту цієї компетентності. Вчена I. Абрамова [1] виділяє аналітичну компетентність у структурі професійної компетентності, вважаючи, що вона є складовою усіх різновидів професійної компетентності. $€$. Гайдамак зазначає, що аналітична компетентність пов'язана з усіма професійними компетентностями, що ускладнює ㄲï виокремлення в самостійну компетентність. Е. Назначило стверджує, що аналітична компетентність $є$ основою професійної компетентності [5].
На основі вище поданого, ми вважаємо, що специфіка діяльності офіцерів-прикордонників пов'язана із розв'язанням завдань на основі запропонованої моделі та основними мисленнєвими процедурами (осмислення, усвідомлення, аналіз, розуміння поставленого завдання), а для цього їм необхідне розвинене аналітичне мислення, тому значущою для офіцерів-прикордонників $\epsilon$ проектно-аналітична діяльність [4].

Отже, теоретико-методологічною основою проектно-аналітичної компетентності $є$ сукупність взаємообумовлених та взаємопов'язаних підходів: філософського, аксіологічного, діяльнісного, контекстного та компетентнісного.

Таким чином, проектно-аналітична компетентність майбутніх офіцерівприкордонників - це сукупність інтегративних характеристик, особистісних та професійних якостей фахівця прикордонного відомства, який володіє спеціальними знаннями, уміннями та здатністю до аналізу та проектування результатів його професійної підготовки.

Проектно-аналітична компетентність розглядається нами як безпосередня складова професійної компетентності майбутніх офіцерівприкордонників. Проектно-аналітична компетентність майбугніх офіцерів-прикордонників (надалі - ПАК МОП) включає проектно-аналітичні знання, навички, вміння, професійно важливі якості, професійний та особистий досвід щодо проектної та аналітичної діяльності, здатність щодо аналітичної обробки інформації, рефлексії та прагнення створювати проекти.

Враховуючи зміст ПАК МОП нами проаналізовано методику її формування.

Методика формування ПАК МОП реалізовується таким чином:

- організація пізнавальної, дослідницької, пізнавальної діяльності курсантів, впровадження в освітній процес системи диференційованих завдань, що забезпечують цілеспрямоване та поетапне засвоєння курсантами способів та переробки інформації;

- практичне закріплення та творча інтерпретація знань, виконання проектно-аналітичних завдань (за критеріями конкретності теми та отриманих результатів; вітагенності результатів (використання життєвого досвіду); можливість представлення результатів в різних формах); на цьому етапі проектно-аналітична діяльність дозволяє внести в освітній процес нові смислові акценти; створити стимули; умови щодо удосконалення суб'єктоб'єктних відносин тощо.

Отже, ретельний аналіз наукової літератури дав 


\section{МЕТОДИКА ФОРМУВАННЯ ПРОЕКТНО-АНАЛТТИЧНОӤ КОМПЕТЕНТНОСТІ МАЙБУТНІХ ОФІЦЕРІВ-ПРИКОРДОННИКІВ У ПРОЦЕСІ ФАХОВОӤ ПІДГОТОВКИ}

можливість розкрити зміст ПАК МОП, а на його основі сформулювати методичні рекомендації щодо її формування.

Висновки. Таким чином, сукупність проаналізованих теоретико-методологічних підходів дозволить всебічно дослідити методику формування проектно-аналітичної компетентності майбутніх офіцерів-прикордонників.

Перспективи подальших досліджень. У контексті розв'язання проблеми формування проектно-аналітичної компетентності майбутніх офіцерів-прикордонників, актуальними $\epsilon$ питання впровадження в освітній процес вищих військових навчальних закладів технології формування зазначеної компетентності.

\section{ЛІТЕРАТУРА}

1. Абрамова И. А. Формирование аналитической компетентности студентов инженерных факультетов вузов аграрного профиля на основе средств и методов информатики: дис. ... канд. пед. наук: 13.00.02 / Иванна Андреевна Абрамова. - Москва: РГБ, 2007. - 179 с.

2. Брюханова Н. О. Концептуальні положення проектування системи педагогічної підготовки майбутніх інженерів-педагогів / Н. О. Брюханова // Проблеми інженерно-педагогічної освіти: зб. наук. пр. / Укр. інж.-пед. акад. - Х., 2012. - Вип. 34-35. - С. 8-13.

3. Волкова Н. П. Педагогіка / Н. П. Волкова. К.: Академія, 2009. - 3-тє видання. -616 с.

4. Вохменцева Е. А. Проектная деятельность учащихся как средство формирования ключевых компетентностей [Текст] // Актуальные задачи педагогики: материалы Междунар. науч. конф. (г. Чита, декабрь 2011 г.). - Чита: Издательство Молодой ученый, 2011. - C. 58-65. - URL https:// moluch.ru/conf/ped/archive/20/1390/ (дата обращения: 06.02.2018).

5. Зеер Э.Ф. Психология профессий: Учебное пособие для студентов вузов. // Э. Зеер / 2еизд., перераб., доп. - М.: Академический Проект; Екатеринбург: Деловая книга, 2003. $336 \mathrm{c}$.

6. Зінчук Н. А. Підготовка майбугніх менеджерів до аналітичної діяльності: проблеми та шляхи їх розв’язання [Електронний ресурс] / Н.А. Зінчук // Теорія та методика управління освітою. 2009. - №2 - - Режим доступу: http:// archive.nbuv.gov.ua/ejournals/ttmuo/2009_2/ 09sinwts.pdf. Е. Коваленко

7. Инженерная педагогіка: ещё один шаг вперед / С. Ф. Артюх, А. Т. Ашеров // Новий колегіум. - 2000. - № 2. - С. 48-49.

8. Коваленко О. Е. Методика професійного навчання. Навчальний посібник // О. Коваленко/ - Харків, $2002-158$ с.

9. Максимова О. О. Формування соціальної компетентності дитини дошкільного віку як запорука її успішної адаптації до навчання в школі / О. О. Максимова // Педагогічна освіта: теорія і практика. Збірник наукових праць / Кам'янецьПодільський національний університет імені Івана Огієнка; Інститут педагогіки НАПН України [гол. ред. Лабунець В.М.]. - Вип.20 (1-2016). - Ч.2. Кам'янець-Подільский, 2016. - С. 229 - 234

10. Овчарук, О. В. Розвиток компетентнісного підходу: стратегічні орієнтири міжнародної спільноти / О. В. Овчарук // Компетентнісний підхід у сучасній освіті: світовий досвід та український перспективи: кол. моногр. - К., 2006. - С. 6-16. - (Бібліотека освітньої політики).

11. Тархан Л.3. Дидактическая компетентность инженера-педагога: теоретические и методические аспекты: [монография] / Ленуза Запаевна Тархан. - Симферополь: КРП “Издательство “Крымучпедгиз”, 2008. - 424 с.

12. Усеинова Л. Ю. Теоретические основы проектирования организации учебноисследовательской лаборатории ВУЗа./ Л.Ю. Усеинова, С. Эмирова // Современные инженерные и инженерно-педагогические технологии. Симферополь: НИЦ КИПУ. - № 5. - 2014 г. C. 107-113.

13. Шаріпова О. С. Гармонізація діяльності як процес забезпечення економічної безпеки підприємства / О. С. Шаріпова, Г.О. Надьон / / Управління проектами та Розвиток виробництва: Зб.наук.пр. - Луганськ: вид-во СНУ ім. В.Даля, 2012. - № 1 (41). - С. 50-55.

\section{REFERENCES}

1. Abramova, I. A. (2007). Formirovanie analiticheskoy kompetentnosti studentov inzhenernyih fakultetov vuzov agrarnogo profilya na osnove sredstv i metodov informatiki [Formation of analytical competence of students of engineering faculties of higher educational institutions of agrarian profile on the basis of means and methods of informatics]. Candidate's thesis. Moscov: RGB, 179 p. [in Russian].

2. Bryuhanova, N. O. (2012). Kontseptualni polozhennya proektuvannya sistemi pedagogichnoyi pidgotovki maybutnih inzheneriv-pedagogiv [Conceptual provisions for designing a system of pedagogical training for future engineers-teachers]. Problems of engineering and pedagogical education. Kharkiv, vol. 34-35, pp. 8- 13. [in Ukrainian].

3. Volkova, N. P. (2009). Pedagogika [Pedagogy]. Kyiv: Akademiya, vol.3., 616 p. [in Ukrainian].

4. Vohmentseva, E. A. (2011). Proektnaya 


\section{МЕТОДИКА ФОРМУВАННЯ ПРОЕКТНО-АНАЛІТИЧНОЇ КОМПЕТЕНТНОСТІ МАЙБУТНІХ ОФІЦЕРІВ-ПРИКОРДОННИКІВ У ПРОЦЕСІ ФАХОВОЇ ПІДГОТОВКИ}

deyatelnost uchaschihsya kak sredstvo formirovaniya klyuchevyih kompetentnostey [Project activity of students as a means of forming key competencie]. Aktualnyie zadachi pedagogiki: materialyi Mezhdunar. nauch. konf. (g. Chita, dekabr 2011 g.). - Actual problems of pedagogy: Proceedings of the International scientific conf. (Chita, December 2011). (pp.58-68). Chita: Izdatelstvo Molodoy uchenyiy. Available at: https://moluch.ru/conf/ped/archive/20/ 1390/(accessed 06.Febr., 2018). [in Russian].

5. Zeer, E.F. (2003). Psihologiya professiy: Uchebnoe posobie dlya studentov vuzov [Psychology of professions: A manual for university students]. Moscov: Akademicheskiy Proekt; Ekaterinburg: Delovaya kniga, 336 p. [in Russian].

6. Zinchuk, N. A. (2009). Pidgotovka maybutnih menedzheriv do analitichnoyi diyalnosti: problemi ta shlyahi yih rozv'yazannya [Preparation of future managers for analytical activity: problems and ways of their solution]. [Electronic resource]. Theory and methodology of education management, no.2. Available at: http://archive.nbuv.gov.ua/ejournals/ ttmuo/2009_2/09sinwts.pdf. E. Kovalenko [in Ukrainian].

7. Artyuh, S. F. \& Asherov, A. T. (2000). Inzhenernaya pedagogika: eschyo odin shag vpered [Engineering pedagogy: one more step forward]. Novyi kolehium, no.2, pp. 48-49. [in Russian].

8. Kovalenko, O. E. (2002). Metodika profesiynogo navchannya [Methodology of professional training]. Tutorial, Harkiv, 158 p. [in Ukrainian].

9. Maksimova, O. O. (2016). Formuvannya sotsialnoyi kompetentnosti ditini doshkilnogo viku yak zaporuka yiyi uspishnoyi adaptatsiyi do navchannya $v$ shkoli [Formation of social competence of a child of preschool age as a guarantee of its successful adaptation to school education] Pedagogical Education: Theory and Practice. Collection of scientific works, Kamenets-Podolsky National University named after Ivan Ogienko; Institute of Pedagogics of National Academy of Sciences of Ukraine. (Ed.). Labunets V.M., vol. 20 (1-2016), part.2., Kam'yanets-Podilskiy, pp. 229 234. [in Ukrainian].

10. Ovcharuk, O. V. (2006). Rozvitok kompetentnisnogo pidhodu: strategichni orientiri mizhnarodnoyi spilnoti [Developing a Competency Approach: Strategic Guidelines for the International Community]. Competency Approach in Modern Education: World Experience and Ukrainian Perspectives. Kyiv, pp. 6-16. [in Ukrainian].

11. Tarhan, L.Z. (2008). Didakticheskaya kompetentnost inzhenera-pedagoga: teoreticheskie i metodicheskie aspektyi [Didactic competence of the engineer-teacher: theoretical and methodical aspects] Simferopol: KRP “Izdatelstvo "Kryimuchpedgiz”, 424 p. [in Russian].

12. Useinova, L. Yu. \& Emirova, S. (2014). Teoreticheskie osnovyi proektirovaniya organizatsii uchebno-issledovatelskoy laboratorii VUZa [Theoretical bases of designing the organization of the educationalresearch laboratory of the university]. Modern engineering and engineering-pedagogical technologies. Simferopol: NITs KIPU, no. 5., pp. 107-113. [in Russian].

13. Sharipova, O. S. \& Nadon, G.O. (2012). Garmonizatsiya diyalnosti yak protses zabezpechennya ekonomichnoyi bezpeki pidpriemstva [Harmonization of activities as a process of ensuring the economic security of the enterprise]. Project Management and Production Development: Zn.uk.pr. Lugansk: SNU im. V.Dalya, no. 1 (41), pp. 50-55. [in Ukrainian].

Стаття надійшла до редакції 06.02.2018

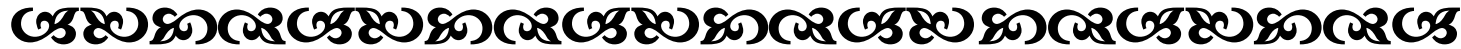

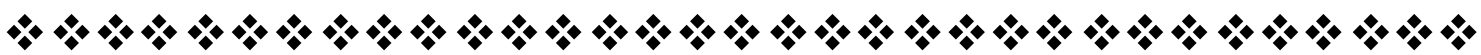

“там'ятай, сьогодні- це те “завтра”, про яке ти хвилювався вчора".

Dейл Карнегі

американський психолог, педагог, письменник

"Майбутнім ми маримо, а сучасним гордуємо: ми прагнемо до того, чого немає, $i$ нехтуємо тим, що є, так ніби минуле зможе вернутись назад, або напевно мусить здійснитися сподіване".

Tригорій Cковорода украӥнський просвітитель-гуманіст, філособ, поет, педагог

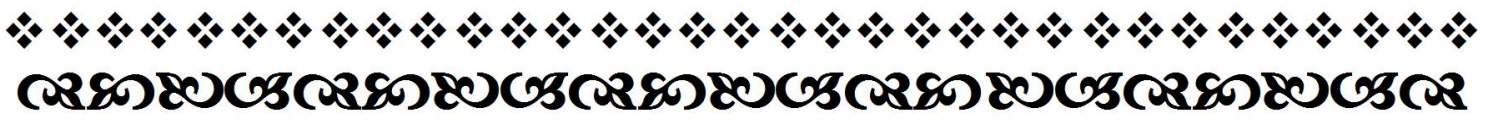

Молодь і ринок №3 (158), 2018 